\title{
Prospect and Challenges of Agricultural Education viz-a-viz Attainment of Millennium Development Goals by 2014
}

\author{
Ola Elijah, Olusoga \\ Department of Agricultural Education \\ Michael Otedola College of Primary Education, Noforija, P.M.B. 1028 Epe Lagos State
}

Doi:10.5901/jesr.2014.v4n7p167

\begin{abstract}
Nigeria and African countries in general, is blessed with so many resources; human, mineral, land and other natural resources. Despite all these poverty, hunger, ill-health (diseases) high mortality rates, discontinuity in educational pursuit and the like, with all the attendant consequences. These are the experience of many African countries today. Nevertheless government at different times have adopted means and programmes, which are either targeted towards overall national development or as a response to immediate or prevailing problems in agriculture, at solving them, most of which have not yielded much result either as a result of ill-motivation or poor implementation. It is in view of this that this paper now proposed effective agricultural education as an avenue towards attainment of Millennium development goals. It exposed various opportunities there in such as potential to become a teacher, be self employed and employer of labour (in crop production, horticulture, ruminant and non ruminant production, poultry and fish production distributor and marketer of agricultural produce) and the challenges towards acquisition of adequate knowledge and skills in agriculture and recommended that government should create a conducive environment for learning and agricultural educators to lay more emphasis on practical agriculture for effective skill acquisition, self-reliance and independence.
\end{abstract}

Keywords: Education, Agriculture, Prospects, Challenges, Millennium Development Goals

\section{Introduction}

In this century $\left(21^{\text {st }}\right)$ when the focus of every government is how to bring about the transformation of the nation, it is a good development to consider the contribution of education (teaching and learning) to the national development. The level of development of a nation is determined by the quality of education. Some development countries of the world such as Europe: Canada, France, Germany and Asia countries: India, Malaysia, Republic of Korea and Thailand to mention a few have been able to earn their status through education.

According to the world bank development report (2011) countries such as Cambodia, India,, Malaysia, Republic of Korea and Thailand invested less in education in the 70's and recorded little achievement in terms of literacy rate and economic growth, within 30 years the story changed when this was realized.

No nation in education and training is imperative if the economy is to be propelled to a higher levels of productivity and income and thereby accelerate the rate of economic growth.

Education increases the member of knowledgable workers by improving their skills and enabling them to see new challenges, enhances occupational mobility, reduces the level of unemployment, increases the earning capacity and productivity of the workforce, improves access to health information which will increase life expectancy, enhances income distribution and social equity. In other words, the economic benefits of human capital formation stem from the fact that people are made more productive by improving their nutrition, health education and other social indices through adequate and proper investments (Adamu, 2002).

The words of Harry (2010) says "upon realization of the fact that the human brain (human resources) is more than any natural resources, most countries of the world (especially Europe, America and Asia) laid the foundation of their development on their human resources. It has been recognized as an instrument of change per excellence. No nation that aspires to greatness can toy with it, thus the saying "if you think education is expensive, try ignorance.

\section{Concept of Agricultural Education}

Agricultural education is a type of vocational training involving the equipping of the learners with the knowledge and skills 
involved in productive agriculture. It involves the training of both the head and the hands of the learners. A exchange in learner is equipped with both the educational and agricultural knowledge (i.e the development of the three domains; cognitive, affective and psychomotor).

Agricultural education entails the use of scientific knowledge in the teaching and learning of food production through the acquisition of knowledge of crop production, livestock management, soil and water conservation and other associated benefits for industrial and human development. It is a type of vocation that emphasizes preparation and participation in an occupation for social value (Odogwu, 2005). Contrary to general education, it is skill-oriented. Apart from being trained as a teacher agricultural education also prepares individual for self-reliance and job creation.

\section{Prospects of Teaching and Learning Agricultural Education}

Agricultural remains the major employers of labour either directly or indirectly. It is the main stay of Nigeria and world economy. Agriculture provides food and drinks, raw materials for industries, income for farmers, revenue for government and source of foreign exchange. In addition source of fuel and power, recreation, tourism and aesthetic value among other things. In view of these numerous benefits, it is important to give the teaching and learning of agricultural education the position it deserves for the millennium goals to be achieved.

Agricultural education opens wide opportunities for many people to be employed. Because it trains individual the knowledge and skill required to be self employed for independent. It is skill-oriented.

Therefore, avenues are created for people to be engaged in the following areas among others.

$>$ Teacher. Though acquisition of knowledge and skills in agricultural education, one may end up becoming a trainer of agriculture in schools and institution of higher learning.

$>$ Opportunity in crop production

$>$ Opportunity is also opened in horticulture.

$>$ Opportunity in poultry keeping.

$>$ Opportunity in ruminant and non ruminant- livestock production.

$>$ Fish farming

$>$ Bee keeping

$>$ Grass cutter farming.

$>$ Feed industry- formulation and manufacture

Venturing into agro-allied products- chemicals (pesticide leads, herbicides, fungicides, fertilizers among others.

If the learners is well groomed or well taught and properly baked, he can go into any of the areas mentioned above and through that assist in the attainment of the millennium development goals by the year 2015 .

The objective of vocational and technical education in Nigeria today (FRN,2004)are such that if and quietly implemented, will bring about the revocation and technical development in Nigeria thereby having a significant and positive impact on the national. Economy these objective include, among others, the training of manpower particularly or professional grades, the provision of technical knowledge and vocational skills, and providing training and skill that lead to production of Craftsman, technicians and others skill personnel. (FRN 2004). The fact remains, however, that none of these will be accomplished of student in scinhools are improperly trained (i.e of poor teaching and learning takes place). Effective training of student cannot be accomplished in the absence of certain ingredients that create conductive environment for teaching and learning

The following, however, among others, are challenges to teaching and learning of agricultureral education in schools.

Inadequate infrastruction facilities. Inadequate laboratories classrooms, staff offices and the like in terms of number and adequately are some of the experiences in schools. This to a large expent may pose challenge to teaching and learning.

Lack of equipment and tools. If the equipment and tools expected in the crop and animal laboratories mechanical workshop, horiticultural garden are not there, there cannot be effective teaching and learning and the consequence is that students will be half- backed. This will have a negative impact on the society and economy, you cannot give what you don't have.

Inadequate teaches/ instructors/ technicians. For effective implementation of any educational programme, adequate human and material resources must be made available to the school. In particular, a large enough number of trained teachers with different types of expertise must be reccuited and posted to the school and when required in 
addition, academic staff must be complemented by non teaching staff. Also, adequate instructional materials must be made available to the trainers for the sake of effectiveness.

Lack of interest in agricultural education programme. The interest of student in agricultural education does not commensurate with the enormous benefits derivable from agricultural. Interest in a course of study is an important fact achievement. Fowlee (2002) observed that people hardly learn anything well unless they are interested in what they are learning. Success an any endeavour is very much tied to interest in such endeavour. The interest of students may be stimulated in particular field through societal attitude, training and quality of lectures, peer group opinions and home factor (Awukwu-Efebo (1999).

\section{Agricultural Education and Millenium Developments Goals}

The idea of a millennium development goals came into being in a consencious reached among member nations (Africa inclusive) on September 8, 2000. It represents a global commitment to improve the economic and social conditions in low income countries of the world. It is a declaration that changed united nations members states to improve economic and social conditions in developing countries through operationalizing a list of 8- point millennium development goals (MDGS) that should be achieved by 2015. These MDGS are as highlighted below.

1. To eradicate poverty and hunger

- Reduce by half the proportion of people living on less than a doller per day $(\$ 1 /$ day)

2. To achieve universal primary education

- Ensure that all boys and girls complete a full course of primary schooling.

3. To promote gender equality and empower women.

- Eliminate gender inequality in primary and secondary education performable by 2005 and at all levels by 2015.

4. To reduce child morality

- Reduce by two-third the mortality rate among children under five.

5. To improve material health

- Reduce by three quarter the material mortality ratio

6. To combat HIVIAIDS, malaria and other diseases

- $\quad$ Halt and begin to reverse the speed of HIVIAIDS

- Halt and begin to reverse the incidence of malarial and other major diseases.

7. To ensure environmental sustainability.

- Integrity the principles of sustainable development in to country's policies and programmers reverse loss of environmental resources.

- Reduce by half the proportion of people without sustainable access to safe drinking water.

- achieve significant improvement in lives of at least 100 million slum dwellers by 2020.

8. To develop a global partnership for development

- integrate a simultaneous pursuit of policies that promote growth among developing countries.

- Looking at the first issue on the goals eradication of poverty and hunger, this is particularly of interest to agricultural. Agricultural education.

Low enrolment in agricultural educational programme. Because of the new of many that the course is for discouraged students, the practical involvement is tedious and laborious, only few students are seen soon interest in pursuing agricultural education, as a course, unlike Accounting, Business education, economic, political science, social studies and the like. This may not be encouraging to the teachers. This may also affect the facilities provided for the trainees and so militating against the attainment of millennium development goals by the year 2015 .

Curriculum implementation, many educators are still in aware of their basic rights and responsibilities. As a matter of fact, many teachers get their selves involve in so many involved in so many legal wed in the course of discharging their duties and the rudiments of the subject may be rubbished when overzealous agricultural science teachers turn the school farm to punishment ground. The school, as a social institution for education has a capacity and needs to facilitate, promote and possibly guide certain form of value equipped for the overall success of various government schemes for our national development.

Effective curriculum delivery in agriculture is measured in term of:

$>$ Acquisition of knowledge in the classroom

$>$ Demonstration of clearly defined learning outcomes 
Outside the classroom situation we have:

$>$ Creative thinking and mastery regarding farm activities

$>$ Entrepreneurial skill and managerial abilities of and off -farm activities.

$>$ Risk taking abilities.

$>$ Display of professional values and ethnics

$>$ Farm and rural minded

$>$ Ability to transmit and impact knowledge to others.

$>$ Poor funding and paying up service. Because of the economic predicament of the nation and the enormous commitments of the government at all levels less than $50 \%$ of the recommended allocation by the United Nations is giving to education (i.e $26 \%$ of the yearly budgetary allocation). This in no small measure is affecting the quality of education in Nigeria with attendant problems.

Is a sure way of achieving that as it provides knowledge and skill for individuals to be self-reliant, independent, get employed and create employment for others. Therefore allowing effective teaching and learning to take place by creating a conducive environment would go a long way. It is also important for agriculture educators to ensure that real practical knowledge and skills are built on the learners to enable their independence in life not only academic exercise or awarding of degrees or certificates alone.

Also, apart from making the school environment conducive for learning by all stakeholder, the educators and trainees should ensure that various researches are carried out, that can bring transformation in all ramifications. It is important that the information about the outcome of various researches get to farmers and agricultural stakeholders. For instance access to research information by farmers in Australia led to favorable circumstances for early agricultural development (Tric and Peel 1989)

Similarly, the case of massagana 99"reported by Yahaya (2003) is worthy of mentioning. In "Massagana 99", communication project was strategically used to reach out to rice farmers so as to increase rice production in the country.

According to United States Agency for development (USDA, 1978) the word "massagana" means bountiful harvest and the "99" of the project title refers to the target yield of 99 cavans ( 1 cavan is equal to 44 kilograms). The result of this projects shows that rice yield in the "massagana 99" increased dramatically by 28\% from 1973 to 1974 and by 1977 yield averaged 3.3 tones percentage. The farmers recorded average gain of $118 \%$. In the same year the Philippines which used to be a rice importing country prior to the project, exported 140, 000 metric tones of rice. Despite transformation problem, unfavorable weather, pest infestation, the social-economic impact of the project on farm families was significantly felt (USAID, 1978).

Agricultural education provides avenue through which knowledge, abilities and skills of a farmers and all agricultural stakeholders can be increased towards attainment of food security for the alleviation of poverty and hunger. To achieve this, agricultural research should be given premium. Such will not find solutions to problem of food alone.

Problems confronting teaching and learning of practical agriculture at different levels since agricultural education curriculum in most Africa countries covers issues of philosophical objectives, values, psychological administrative considerations and technological development.

Furthermore, agricultural educations is capable of empowering women, as it built on individuals the knowledge and skills required for individuals to be independent. "Knowledge is power". Though the acquisition of necessary skills in agriculture, women can be involved in various aspects of agricultural activities ranging from production, distribution and marketing of produce.

Also, for good health living and reduction in mortality rates, good quality and quantity food cannot be left out. This has direct impact on human health as well as combats so many diseases. This comes from agriculture.

\section{Conclusion and Recommendation}

From the beginning of creation, agriculture has been and will continue to be man's cardinal vocation to subdue and replenish the earth and has since become the life wire of man. Therefore, it will not amount to an exaggeration, if huge resources are invested on agricultural education.

Conclusively, therefore, for the attainment of the millennium, development goals not to be a mirage in the year 2015 and in the generations to come, agricultural education must be given a proper attention and placed in the right position. This is only possible through quality teaching and learning. 


\section{Recommendations}

In order to reach our goals and for the transformation of the nation's economy and in the interest of the well being of Nigerians. I want to make the following recommendations

* Government at all levels should ensure adequate funding of agricultural education programmes for effective curriculum implementation. Non-governmental organizations and individual should also give a support.

* Provision of adequate infrastructural facilities, equipment and manpower for effective teaching and learning.

* Agricultural educators should lay more emphasis on practical aspects for the asked of skill acquisition

* In view of the enormous benefits in agriculture and the job opportunities there-in, parents and membership of the society at large should encourage youth to take up agriculture as profession and therefore enroll in agricultural education programmes instead of clustering in some programmes where they will not be independent.

\section{References}

Adamu P.A (2002) The impact of human capital on economic growth in Nigeria. An error correction approach. Human resource development in Africa- selected papers for 2002 annual conference. The Nigeria economic society.U.I, Ibadan, Nigeria.

Awotua-Efebo, E.B. 1999). Effective teaching principles and practices Port Harcourt. Pen graphics publication.

Federal republic of Nigeria (2004). Revised national policy on education. Federal ministry of education printing division. Lagos.

Fowler I. 92002). Critical factors affecting students performance in science. Singapore cleanement publishers.

Harry Deinibiteim (2010). The centrality of human capital development Programme. Journal of sustainable development in Africa 12(5), 2010. http:// wiki answer.com/Q/what is development, http:// Wikipedia.org/wiki/concept of education.

Odugwu A.G (2005) An introduction to vocational and technical education In Nigerian schools and colleges, Owerri- Nigeria wisdom people publishers.

Tribe, D.E and Peel, L.J (1989) Innovation, Science and the Farmer. In Technology in Australia, 17788-1988:1-70

United States Agency for International Development (USAID), (1978). "Massagana99" in Phillipines Washington D.C. clearinghouse on Development Communication 58p.

United States Department of Agric (USDA) (2008) "food security in the united states. Measuring household food security" http://www.ers.usda.gov/briefing/food security// measurement.htretrieved 23/08/2008.

World Bank development report (2010). http//Date. World Bank.or/Tapic/Poverty. Retrieved on Saturday April 2011. 2:15 pm.

Yahaya, M.K. (2003) Development Communication Lesson from social change and engineering projects. Corporate graphic Ltd. Ibadan ISBN:978-36756-2-1 